\title{
Stonefly (Plecoptera) fauna in a mountainous area of Central Brazil: composition and adult phenology
}

\author{
Pitágoras C. Bispo ${ }^{1}$ \\ Cláudio G. Froehlich ${ }^{1}$ \\ Leandro G. Oliveira ${ }^{2}$
}

\begin{abstract}
A survey of the stonefly (Plecoptera) fauna of streams of the Almas River basin, Pirenópolis, Goiás State, Central Brazil, is presented as well as data of some factors that could affect the temporal distribution of the adults. For checking adult phenology, light sources were used in three stations from June 1993 to Jully 1994. The sampled individuals were identified to species or morphospecies, as possible. In this study, 301 individuals belonging to the perlid genera Anacroneuria Klapálek, 1909, Kempnyia Klapálek, 1916 and Macrogynoplax Enderlein, 1909 were collected. Adults of most species were collected along the studied period, except for those of Kempnyia that were restricted to the warm-rainy season, the same pattern for this genus in southeastern Brazil. Although adults of most species were collected along most of the studied period, the largest number of adults was collected in the months with larger mean temperatures, showing a clear seasonality in abundance.

KEY WORDS. Plecoptera, Central Brazil, adult phenology, seasonality
\end{abstract}

The Plecoptera are still little known in Brazil, mainly as regards the biological and ecological aspects of the group (FROEHLICH \& OLIVEIRA 1997). Most of the published papers, by contrast, have emphasized taxonomical aspects (FrOEHLICH 1990, 1994). Considering the adult phenology, only two works were available: one about Kempnyia Klapálek, 1916 and Macrogynoplax Enderlein, 1909 of southeastern Brazil (FrOEHLICH 1991), and another about some species of Tupiperla Froehlich, 1969 that includes a species from Central Brazil (Pirenópolis, Goiás State) (FROEHLICH 2000).

This is the first study, including adult phenology, of the Plecoptera in the "cerrado" biome, Brazilian Savanna of Goiás State. The aims of this work were to survey the Plecoptera fauna in streams of the Almas River (Rio das Almas) basin, Pirenópolis, Goiás, as well as to evaluate some factors that could influence the temporal distribution of adults.

1) Departamento de Biologia, Faculdade de Filosofia Ciências e Letras de Ribeirão Preto, Universidade de São Paulo. Avenida Bandeirantes 3900, 14040-901 Ribeirão Preto, São Paulo, Brasil. E-mail: pitbispo@usp.br and cgfroeh@usp.br

2) Departamento de Biologia Geral, Instituto de Ciências Biológicas, Universidade Federal de Goiás. Campus Samambaia, Caixa Postal 131, 74001-970 Goiânia, Goiás, Brasil.

E-mail: lego@icb1.ufg.br 


\section{MATERIAL AND METHODS}

\section{Study area}

This study was carried out in the Almas River basin. The sources of this river are located in the Sierra of the Pireneus, Pirenópolis (15'51'S and 48 $\left.57^{\circ} \mathrm{W}\right)$, Goiás, and comprise a number of streams descending steep slopes with stony or sandy bottoms but also with some pools retaining leaf accumulations. These streams run on the western slopes of the mountains and are part of the Amazon basin.

According to NIMER (1989), the area presents a semi-humid tropical climate with a summer rainy season (higher precipitation from December to February) and a winter dry season from May to September.

\section{Samplings and taxonomic identification}

Samplings of adults were done in three stations (banks of the streams) during 14 months (June 1993 to July 1994). Inferno Stream Station: first order portion, located high on the Serra dos Pireneus, at an altitude of $1100 \mathrm{~m}$ a.s.l. The area is forested. Almas River Station: 4th order, at $750 \mathrm{~m}$ a.s.l., within a camping club where tourists cause an anthropic impact. Vagafogo Stream Station: a tributary of Almas River downstream from the town at an altitude of $710 \mathrm{~m}$ a.s.1., in a 1 st order stretch. It is located within an ecological reserve maintained by conservation society Funatura. This area is also forested.

Adults were collected from dusk on (about four hours by night in each station) with the aid of a blended-light lamp powered by a portable generator, and a white sheet (VANZOLINI \& PAPAVERO 1967), and were fixed in 80\% alcohol. Adults were identified to species when possible, or to morphospecies. For identifications the papers by ZWICK (1972), BENEDETTO (1974) and FROEHLICH (1969, 1984a,b,c, 1988, 1990, 1994) were used. The specimens are with the first two authors for taxonomic study, afterwards they will be deposited in the Museu de Zoologia da Universidade de São Paulo (MZSP).

\section{Abiotic Factors}

Monthly means of temperature, precipitation and relative air humidity for Pirenópolis ( $18 \mathrm{~km}$ from the most distant collecting station, Inferno Stream Station) were obtained at the 10th Meteorological District of the Ministry of Agriculture, Goiânia, Goiás.

\section{RESULTS}

In this study, 301 individuals belonging to three genera of Perlidae (Anacroneuria Klapálek, 1909, Kempnyia and Macrogynoplax) were collected. Specimens of the genus Tupiperla (Gripopterygidae) were also collected but are not considered in the present study. They belong to a species described recently, $T$. oliverai Froehlich, 1998 (FROEHLICH 1998). A study on ecological aspects of Tupiperla, including the phenology of T. oliverai, is presented in FROEHLICH (2000). No adults of Gripopteryx Pictet, 1841 (Gripopterygidae) were collected, only nymphs. The largest numbers of perlid adults occurred in October and November 1993. In June and July 1994 no adult was collected. Anacroneuria comprised $86.7 \%$ of all adults, separated into eight 
morphospecies. Four species of Kempnyia were registered: K. neotropica Jacobsen and Bianchi, 1905, K. vanini Froehlich, 1988 and two new species (Kempnyia sp. 1 and Kempnyia sp. 2). A single female of Macrogynoplax was collected. The data referring to collected adults are shown in table I.

Table I. Total number of perlid adults collected in three sampling stations at streams of Almas River basin, Pirenópolis, Goiás, Brazil, from June 1993 to July 1994.

\begin{tabular}{|c|c|c|c|c|c|c|c|c|c|c|c|c|c|c|c|}
\hline \multirow{2}{*}{ Species } & \multicolumn{7}{|c|}{1993} & \multicolumn{7}{|c|}{1994} & \multirow{2}{*}{ Total } \\
\hline & Jun & Jul & Aug & Sep & Oct & Nov & Dec & Jan & Feb & Mar & Apr & May & Jun & Jul & \\
\hline Anacroneuria sp. 1 & 0 & 4 & 1 & 3 & 8 & 13 & 13 & 8 & 14 & 2 & 2 & 1 & 0 & 0 & 69 \\
\hline Anacroneuria sp. 2 & 0 & 0 & 0 & 2 & 2 & 7 & 4 & 6 & 9 & 7 & 0 & 3 & 0 & 0 & 40 \\
\hline Anacroneuria sp. 3 & 1 & 0 & 8 & 8 & 24 & 28 & 0 & 3 & 11 & 4 & 4 & 4 & 0 & 0 & 95 \\
\hline Anacroneuria sp. 4 & 0 & 0 & 0 & 0 & 0 & 2 & 0 & 0 & 0 & 0 & 0 & 0 & 0 & 0 & 2 \\
\hline Anacroneuria sp. 5 & 0 & 0 & 0 & 0 & 1 & 0 & 1 & 0 & 1 & 0 & 1 & 0 & 0 & 0 & 4 \\
\hline Anacroneuria sp. 6 & 0 & 0 & 0 & 2 & 3 & 2 & 0 & 0 & 0 & 0 & 0 & 0 & 0 & 0 & 7 \\
\hline Anacroneuria sp. 7 & 0 & 0 & 0 & 1 & 0 & 1 & 0 & 0 & 3 & 0 & 0 & 0 & 0 & 0 & 5 \\
\hline Anacroneuria sp. 8 & 0 & 1 & 0 & 3 & 6 & 12 & 5 & 2 & 3 & 4 & 2 & 1 & 0 & 0 & 39 \\
\hline Kempnyia sp. 1 & 0 & 0 & 0 & 0 & 5 & 2 & 0 & 0 & 0 & 0 & 0 & 0 & 0 & 0 & 7 \\
\hline Kempnyia sp. 2 & 0 & 0 & 0 & 1 & 20 & 0 & 0 & 0 & 0 & 0 & 0 & 0 & 0 & 0 & 21 \\
\hline Kempnyia neotropica & 0 & 0 & 0 & 0 & 1 & 4 & 2 & 0 & 0 & 0 & 0 & 0 & 0 & 0 & 7 \\
\hline Kempnyia vanini & 0 & 0 & 0 & 0 & 0 & 2 & 1 & 0 & 0 & 1 & 0 & 0 & 0 & 0 & 4 \\
\hline Macrogynoplax sp. 1 & 0 & 0 & 1 & 0 & 0 & 0 & 0 & 0 & 0 & 0 & 0 & 0 & 0 & 0 & 1 \\
\hline Total & 1 & 5 & 10 & 20 & 70 & 73 & 26 & 19 & 41 & 18 & 9 & 9 & 0 & 0 & 301 \\
\hline
\end{tabular}

Considering the phenology of the adults, perlids were absent only in June and July 1994 (the two months with the lowest mean temperatures), but were present in the same months in 1993. Most species of Anacroneuria apparently fly along the year, but in low numbers during the colder months. Adults of Kempnyia were collected in a more restricted period, most specimens ocurring from September to December 1993, but one specimen of $K$. vanini was collected in March 1994 (Fig. 1).

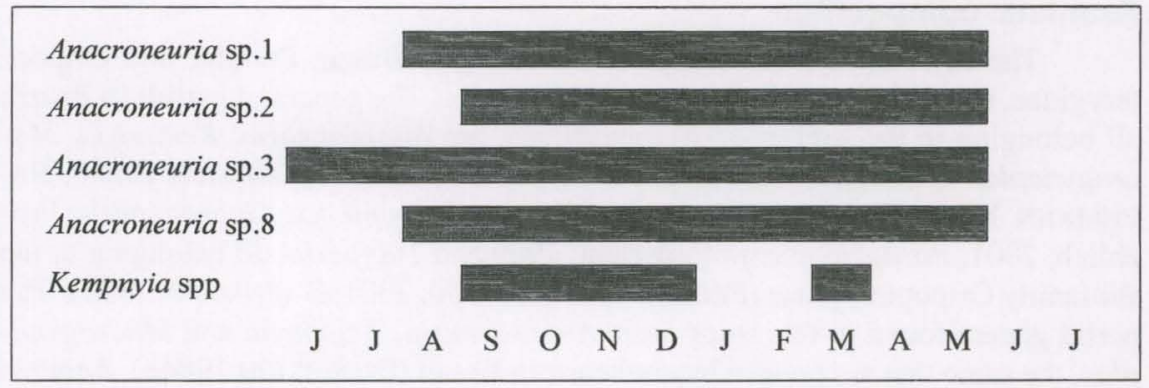

Fig. 1. Adult phenology of the most frequent perlid morphospecies from June 1993 to July 1994 , in the area of Pirenópolis, Goiás, Brazil.

The largest number of adults was collected in the period with larger mean temperatures, showing abundance seasonality. The annual variation in the number of adults was more influenced by the temperature than by the precipitation and/or air humidity (Fig. 2). 


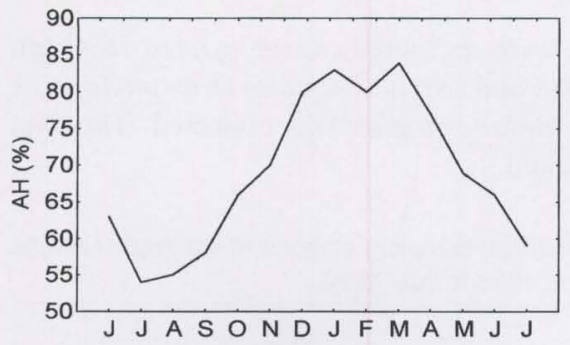

A: AH (air humidity)

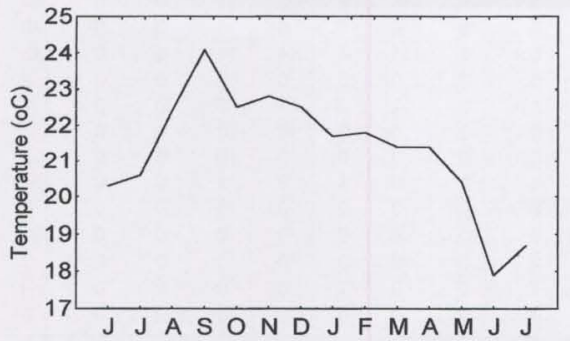

C: temperature

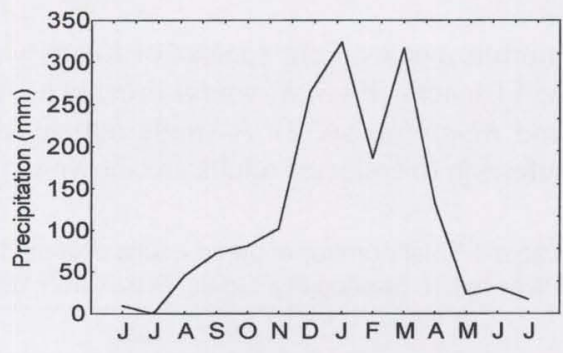

B: precipitation

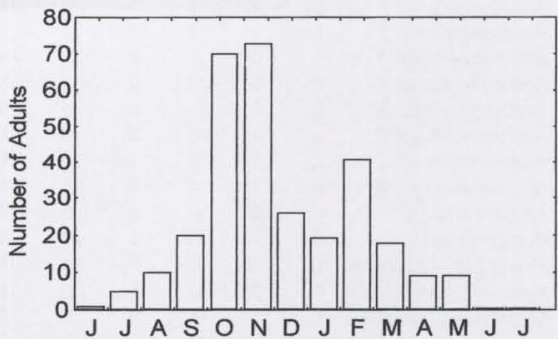

D: number of adult

Fig. 2. Monthly average values of: (A) relative air humidity, (B) precipitation, (C) temperature, and (D) monthly adult Plecoptera number, Almas River basin, Pirenópolis, Goiás, Brazil, from June 1993 to July 1994.

\section{DISCUSSION}

\section{Faunistic composition}

The two families of Plecoptera occurring in Brazil, Perlidae and Gripopterygidae, were registered in the area of Pirenónolis. The genera of perlids in Brazil, all belonging to the subfamily Acroneuriinae, are Anacroneuria, Kempnyia, Macrogynoplax and Enderleina Jewett, 1960 (JEWETT 1960; FROEHLICH 1984b; BACHMANN 1995). Those of Gripopterygidae are Gripopteryx, Guaranyperla Froehlich, 2001, Paragripopteryx Enderlein, 1909 and Tupiperla, all belonging to the subfamily Gripopteryginae (FROEHLICH 1969, 1990, 2001; BACHMANN 1995). The perlid genera found in this study were Anacroneuria, Kempnyia and Macrogynoplax, the same that are present in southeastern Brazil (FROEHLICH 1984b). Anacroneuria is widespread in the Neotropical Region. Eight morphospecies were distinguished in the study area. The genus Kempnyia only was known from southern Brazil up to the mountains of southeastern Brazil, here its geographical range is extended to central Brazil. Kempnyia neotropica, is a widespread species; $K$. vanini is known from São Paulo and Minas Gerais States; and two new species were found in the study area. Of the genus Macrogynoplax, M. veneranda Froehlich, 1984 is known from the coastal mountains of São Paulo (FROEHLICH 1984b) and other 
species occur in the Amazonian forest of northern South America (ZWICK 1973; STARK \& ZWICK 1989; RIBEIRO-FERREIRA \& FROEHLICH 1999). In the study area some nymphs and an adult female were collected, but were insufficient for specific determination. Gripopteryx (nymphs) and Tupiperla (FROEHLICH 1998) were the gripopterygids collected in the area. The latter two genera are for the first time recorded for the Goiás State, representing their northernmost ocurrence in Brazil. The second autor (C.G.F), however, has some nymphs of Gripopteryx collected near Brasília, Distrito Federal.

\section{Adult phenology}

Emergence in Plecoptera may be synchronized, all adults appearing in a short period of time, or it may be extended (HYNES 1976; DUFFIELD \& NELSON 1990). When studying adult phenology, a distinction must be made between flight period and emergence period. The flight period is larger that the emergence period and depends also on the duration of the adult life, as stated by DUFFIELD \& NELSON (1990).

Temperature is one of the main factors that regulate the life cycles of many insects, accordind WARD \& STANFORD (1982), this factor plays a major role in regulating seasonal changes in growth rates of aquatic insects. The temperature associated with photoperiod changes may have a greater influence than the developmental stage, i.e., the emergence of adults depends only in part on the growth rate of immatures (WARD \& STANFORD 1982). Probably temperature, nymph developmental stage and photoperiod interact on the emergence period but the results vary according to the group or species studied (HYNES 1970). In the tropics differences in photoperiod are smaller than in temperate regions and were not considered in the present study.

The various emergence patterns and flight periods vary according to historical, geographical or ecological causes. These patterns are well-known for the Holarctic Region (FruTIGER 1987; DUFFIELD \& NELSON 1990; DIETERICH \& ANDERSON 1995). Regarding tropical regions, there is a scarcity of information on the subject. ZWICK (1976), studying the emergence of adult stoneflies in a mountain stream in Central Africa, verified that rainfall was seasonal but that air and water temperatures were non-seasonal. The two most abundant species, studied by him, showed non-seasonal emergence. FROEHLICH (1991) studied the flight periods of Macrogynoplax and Kempnyia (Perlidae) in southeastern Brazil, mainly in subtropical areas. Macrogynoplax veneranda flew all along the year. Kempnyia adults were seasonal, flying during the warm, rainy season. The same pattern was observed in the species of Kempnyia from the area of Pirenópolis, most adults having been collected from September to December. The sole specimen of Kempnyia collected outside this period (March) belonged to $K$. vanini, a species that flies from December to April in southeastern Brazil (FROEHLICH 1991). Most adults in the subtropical climate of altitude in southeastern Brazil, as, for example, in Campos do Jordão, São Paulo State, tend to have seasonal flight periods. In the tropical area of the Pedregulho, São Paulo State, with higher temperatures, several species of Anacroneuria flew the year round, but the most abundant one showed a seasonal variation 
in abundance. In other localities of the subtropical part of São Paulo State, Anacroneuria species may have seasonal emergence patterns, whereas most gripopterygids fly the year round. In the area of Pirenópolis, most species of Anacroneuria flew practically throughout the year.

In spite of the fact that in the area of Pirenópolis most species of Plecoptera, except those of Kempnyia, fly the year round, numbers varied greatly along the year. Collections of Trichoptera adults in the same area showed that an increase in numbers started with the beginning of the increase in temperature and was maintained until the beginning of the rainy season, when numbers declined (L.G. Oliveira, unpublished data). The temperature in the area had a small variation during the study period, but clearly influenced the numbers of adults collected, no adult was collected in the two months with the lowest temperatures. FERREIRA \& FrOEHLICH (1992), in their study on the Ephemeroptera of Pedregulho, stated that adults occur all months of the year, but that the activity of these insects was limited in colder days. The greater activity during warmer periods may lead not only to a larger number of adults collected, but also to an increased fitness, measured by an increase in their reproductive activity. The data obtained in this study agree with the pattern observed in collections made in southeastern Brazil, i.e the largest number of adults reached during warm and rainy season.

ACKNOWLEDGEMENTS. To FUNAPE-UFG for financial support during field work; to CAPES and to FAPESP (proc. 98/11074-3) for scholarships to the first author; to CNPq for a research fellowship to the second (301247/96-0) and third (300833/98-9) authors.

\section{REFERENCES}

Bachmann, A.O. 1995. Insecta Plecoptera, p. 1093-1111. In: E.C. Lopretto \& G. Tell (Eds). Ecosistemas de Aguas Continentales. Metodologias para su Estudio. La Plata, Ediciones Sur, Vol. 3, p. 897-1401.

Benedetto, L. 1974. Clave para la determinacion de los plecopteros Sudamericanos. Stud. Neotrop. Fauna Environ. 9: 141-170

DieTERICH, M. \& N.H. ANDERSON. 1995. Life cycles and food habitats of mayflies and stoneflies from temporary streams in western Oregon. Freshw. Biol. 34: 47-60.

DUfFIELD, R.M. \& C.H. NeLSON. 1990. Seasonal emergence patterns and diversity of Plecoptera on Big Hunting Creek, Maryland, with a checklist of the stoneflies of Maryland. Proc. Entomol. Soc. Wash. 92 (1): 120-126.

Ferreira, M.J.N. \& C.G. Froehlich. 1992. Estudo da Fauna Ephemeroptera (Insecta) do Córrego do Pedregulho (Pedregulho, SP, Brasil) com aspectos da biologia de Thraulodes schlingeri Traver \& Edmunds, 1967. Revta bras. Ent. 36 (3): 541-548.

FroeHLich, C.G. 1969. Studies on Brazilian Plecoptera 1. Some Gripopterygidae from the Biological Station at Paranapiacaba, State of São Paulo. Beitr. Neotrop. Fauna 6 (1): 17-39.

. 1984a. Brazilian Plecoptera 2. Species of the serrana group of Kempnyia (Plecoptera). Aquatic Insects 6 (3): 137-147.

.1984b. Brazilian Plecoptera 3. Macrogynoplax veneranda sp. n. (Perlidae: Acroneuriinae). Annals Limnol. 20 (1-2): 39-42.

1984c. Brazilian Plecoptera 4. Nymphs of perlid genera from southeastern Brazil. Annals Limnol. 20 (1-2): 43-48.

1988. Brazilian Plecoptera 5. Old and new species of Kempnya (Perlidae). Aquatic Insects 
10 (3): $153-170$.

. 1990. Brazilian Plecoptera 6. Gripopteryx from Campos do Jordão, State of São Paulo (Gripopterygidae). Stud. Neotrop. Fauna Environ. 25 (4): 235-247.

. 1991. Flight periods of Kempnyia and Macrogynoplax (Plecoptera: Perlidae) in southeastern Brazil, p. 353-357. In: J. AlBA-TERCEDor \& A. SANCHEZ-ORTEGA. (Eds). Overview and strategies of Ephemeroptera and Plecoptera. Gainesville, Sandhill Press, XIV+558p.

(3): $1-13$.

1998. Seven new species of Tupiperla (Plecoptera: Gripopterygidae) from Brazil, with a revision of the genus. Stud. Neotrop. Fauna Environ. 33: 19-36.

2000. Biological observations on Tupiperla (Plecoptera: Gripopterygidae). Rev. Brasil. Biol. 60 (3): 447-450.

.2001. Guaranyperla, a new genus in the Gripopterygidae (Plecoptera). Trends in Research in Ephemeroptera and Plecoptera. New York, Kluwer/Plenum, XIII+478p.

Froenlich, C.G. \& L.G. Oliveira. 1997. Ephemeroptera and Plecoptera nymphs from riffles in low-order streams in southeastern Brazil, p. 180-185. In: P. LANDOLT \& M. SARTORI (Eds). Ephemeroptera \& Plecoptera: Biology-Ecology-Systematics. Fribourg, MTL, XI+569p.

Frutiger, A. 1987. Investigations on the life-history of the stonefly Dinocras cephalotes Curt. (Plecoptera: Perlidae). Aquatic Insects 9 (1): 51-63.

Hynes, H.B.N. 1970. The Ecology of Running Waters. Liverpool, University Press, XXIV+555p.

. 1976. Biology of Plecoptera. Annu. Rev. Entomol. 21: 135-153.

JewETT JR., S.G.. 1960. Notes and descriptions concerning Brazilian stoneflies (Plecoptera). Arq. Mus.

Nac., Rio de Janeiro, 50: 167-184.

NIMER, E. 1989. Climatologia do Brasil. Rio de Janeiro, IBGE, 421p.

Ribeiro-Ferreira, A.C. \& C.G. Froehlich. 1999. New species of Macrogynoplax Enderlein 1909 from north Brazil (Plecoptera: Perlidae: Acroneurinae). Aquatic Insects 21: 133-140.

STARK, B.P. \& P. ZWICK. 1989. New species of Macrogynoplax from Venezuela and Surinam (Plecoptera: Perlidae). Aquatic Insects 11 (4): 274-255.

VAnzolini, P.E. \& N. PAPAVERo. 1967. Manual de Coleta e Preparação de Animais Terrestres e de Água Doce. São Paulo, Secretaria de Estado da Agricultura de São Paulo, 223p.

WARD, J.V. \& J.A. STANFORD. 1982. Thermal responses in the evolutionary ecology of aquatic insects. Annu. Rev. Entomol. 27: 97-117.

Zwick, P. 1972. Die Plecopteren Pictets und Burmeisters, mit Angaben über weitere Arten (Insecta). Rev. Suisse Zool. 78 (58): 1123-1194.

1973. Die Plecopteren Arten Enderleins (Insect); Revision der typen. Annals. Zool. 30 (16): 471-507.

. 1976. Neoperla (Plecoptera, Perlidae) emerging from a mountain stream in Central Africa. Int. Rev. Ges. Hydrobiol. 61 (5): 683-697.

Received in 23.III.2001; accepted in 05.VII.2002. 